\title{
An Empirical Bivariate Study: Understanding Organizational Culture Dimensions Impacting Employee's Performance in IT Industry, Tamilnadu
}

\author{
${ }^{1}$ M.Karthik, ${ }^{2}$ Dr. A Vasumathi \\ ${ }^{1}$ Ph.D Scholar, ${ }^{2}$ Associate Professor \\ VIT Business School, VIT University.
}

\begin{abstract}
The purpose of this paper is to determine the level to which organizational culture is an expounding variable for the employee's performance that leads to overall organizational productivity. Alharbi Awadh (2013) found that the organization culture helps in internalizing joint relationship that leads to manage effective organizational processes. Mullins and Peakock (1991) reported that empowered employees have a greater sense of organizational loyalty, job satisfaction and motivation. Jorgensen (2005) stated that job rotation enhances employee's career, improves productivity and employee retention. Reviews of empirical and theoretical studies revealed that limited researches were done in IT Sector on organizational culture dimensions towards employee's performance. Hence, the goal of this paper is to find out significant relationship between organizational culture dimensions in terms of experience, versatility in the job, freedom in expressing concerns, influencing the decisions and rights to take necessary decisions over the employee's performance attributes in IT industry at Chennai region. The study found a positive relationship between freedom in expressing concerns and the employee's competitiveness towards the job. The study also found a positive correlation between influencing the decisions that affects the employees and the employees being resourcefulness. The study also found a positive correlation between the support and authority to make the decisions necessary for accomplishing the tasks and the employees being initiative. The study also revealed the significant difference between the experience of the employees and their responses towards feeling versatility in their job which has greater scope for career growth. The study also found a significant variance between experience of the employees and employee's performance attributes.
\end{abstract}

Keywords: Organizational culture, Employee rights and empowerment, Job description, Employee performance

\section{INTRODUCTION}

Hofstede (1984) stated that culture can be defined as a collective programming of mind in which distinguishes the members of one category of people from another. Brooks (2006) revealed that the loyalty of employee relies upon knowledge and awareness of culture that improves behavior of the organization. Kotter and Heskett (1992) stated that culture has generally been interrelated to the management in current scenario. Schein (1995) put forwarded that he set of norms, values and beliefs helps in perfect association between certain characteristics of organizational culture. Hodgetts and Luthans (2003) indicated at various levels of organizational culture, different background, ethics and racial differences impact upon the performance. Robbins \& Sanghi (2007) established the attraction of organization norms, values and beliefs have strong impact upon performance and sustainability. Stewart (2010) stated that the norms of employees impact upon sustainable performance and management of organization culture as it leads to attainment of profitability. According to Titiev (1959) the organizational culture becomes the core for the cognitive systems of human that helps in improving thinking and decision making processes. Schein (1990) described that the culture of organization has been affected by attitudes, norms and beliefs that lead to strong communication between employees. Tichy (1982) established that the survival of culture in an organization lies upon national and foreign culture differentiation in culture management. Research objectives

1. To find the relationship between organizational culture attributes and employee's productivity.

2. To study association between experience of the employees and versatility in their job.

3. To find the variance between experience of the employees and their response towards performance attributes.

\section{RELATED WORK}

\section{A. Employee Rights and Empowerment}

Dia Zeglat, Mohammad Aljaber (2014) have found that structural and psychological empowerment positively and significantly influence customer-oriented behavior. Hechanova (2006) found that psychological empowerment was positively correlated with performance. Jalal Hanaysha, Putri Rozita Tahir (2016) found that employee empowerment have a significant positive effect on job satisfaction.

\section{B. Job Description and Role Clarity}

A Moeed Abid, Ambreen Sarwar, Abdul Hannan (2013) revealed a strong positive relation relationship between jobs design and employee satisfaction. Anas Ghazi Alam Edien (Oct 2015) found that job analysis plays significant role toward effective decisions leading to the employee's growth of the organization. Anbarasu Thangavelu, Dr. Clement Sudhahar (2017) through their research insisted that the total IT experience of the respondents does not have any 
significant relationship with either the job satisfaction dimensions or the employee perception.

\section{RESEARCH METHODOLOGY}

\section{A. Type of Research and Sample Size}

Descriptive study is adopted in this research. The size of the sample is 300 employees working in IT industry situated in and around Chennai, Tamilnadu. The sampling technique used was Convenient sampling.

\section{B. Research instruments}

This research study is an empirical in nature. Primary data were collected through well designed questionnaire.

\section{Data Analysis Procedures}

The collected data were entered in SPSS software version 17.0 and different statistical tools were used to analyze the data. Conclusions were drawn based on the findings of the research.

\section{TABLE I. RELIABILITY STATISTICS}

\begin{tabular}{|c|c|c|}
\hline $\begin{array}{c}\text { Cronbach's } \\
\text { Alpha }\end{array}$ & $\begin{array}{c}\text { Cronbach's Alpha Based } \\
\text { on Standardized Items }\end{array}$ & N of Items \\
\hline .870 & .869 & 16 \\
\hline
\end{tabular}

From Table 1, Cronbach's alpha is $\mathbf{0 . 8 7 0}$, which indicates that the questionnaire has a high level of internal consistency.

\section{DATA ANALYSIS}

\section{A. Correlation Analysis}

1) Relationship between Organizational Culture Attributes and Employees' Productivity.

Table 1, infers a positive correlation (0.218) between freedom in expressing views and concerns and the respondent's competitiveness towards the job. The study also found a positive correlation (0.233) between influencing the decision that affects the respondents and the respondents being resourcefulness. The study also found a positive correlation (0.238) between the support and authority to make the decisions necessary for accomplishing the tasks and the respondents being initiative.

\section{B. Chi-Square Test}

H1 There is a significant association between experience of the respondent and their response towards feeling versatility in the job which has greater scope for career growth.

\section{Chi-Square Test}

H1 There is a significant association between experience of the respondent and their response towards feeling versatility in the job which has greater scope for career growth.
From Table 2, it infers that 88 respondents out of 300 (29\%) strongly agreed that they were able to feel versatility in their job which has greater scope for career growth. The table also infers that 108 respondents out of $300(36 \%)$ agreed that they were able to feel versatility in their job which has greater scope for career growth. Eighty three respondents out of 300 (28\%) were neutral in feeling versatility in their job which has greater scope for career growth. The table also infers that 13 respondents out of $300(4 \%)$ disagreed in feeling versatility in their job which has greater scope for career growth. Only 8 respondents out of 300 (3\%) strongly disagreed in feeling versatility in their job which has greater scope for career growth.

From Table 3, the Pearson Chi-square value (0.020) is lesser than the Hypothetical value of 0.05 . Hence, alternative Hypothesis is accepted. Hence there is a significant difference between the experience of the respondents and their response towards feeling versatility in their job which has greater scope for career growth.

Table 4 , infers that the lambda value is 0.078 , which infers that there is $7.8 \%$ error can be reduced in predicting whether the employees were able to feel versatility in their job which has greater scope for career growth by knowing the respondent's experience.

Table 5, shows the Crammer's V value is 0.163 , it infers that there is no association between experience of the respondents and their response towards feeling versatility in their job which has greater scope for career growth.

\section{ANOVA-One Way}

$\mathrm{H} 2$ There is a significant variance between experience of the respondents and the performance attributes.

$\mathrm{H} 2 \mathrm{a}$ There is a significant variance between experience of the respondents and their responses towards quality of work.

$\mathrm{H} 2 \mathrm{~b}$ There is a significant variance between experience of the respondents and their responses towards quantity of work.

$\mathrm{H} 2 \mathrm{c}$ There is a significant variance between experience of the respondents and their responses towards job knowledge.

$\mathrm{H} 2 \mathrm{~d}$ There is a significant variance between experience of the respondents and their responses towards working independently without supervision.

$\mathrm{H} 2 \mathrm{e}$ There is a significant variance between experience of the respondents and their responses towards matching of skills and proficiencies with the role. 
$\mathrm{H} 2 \mathrm{f}$ There is a significant variance between experience of the respondents and their responses towards ability in meeting deadline and managing time effectively.

$\mathrm{H} 2 \mathrm{~g}$ There is a significant variance between experience of the respondents and their responses towards identifying top accomplishments during the performance review.

TABLE II. CORRELATIONS

\begin{tabular}{|l|l|c|c|c|c|}
\hline \multicolumn{2}{|c|}{$\begin{array}{c}\text { Correlation } \\
\text { Coefficient }\end{array}$} & $\begin{array}{c}\text { Adaptabilit } \\
\text { y }\end{array}$ & $\begin{array}{c}\text { Initiativ } \\
\text { e }\end{array}$ & $\begin{array}{c}\text { Resourcefulnes } \\
\text { s }\end{array}$ & $\begin{array}{c}\text { Competitivenes } \\
\text { s }\end{array}$ \\
\hline $\begin{array}{l}\text { Freedom } \\
\text { Expressing } \\
\text { Concerns }\end{array}$ & $\begin{array}{l}\text { Pearson } \\
\text { Correlatio } \\
\mathrm{n}\end{array}$ & .037 & .203 & .161 & .218 \\
\hline $\begin{array}{l}\text { Influence the } \\
\text { Decision }\end{array}$ & $\begin{array}{l}\text { Pearson } \\
\text { Correlatio } \\
\mathrm{n}\end{array}$ & .045 & .180 & .233 & .214 \\
\hline $\begin{array}{l}\text { Decisions } \\
\text { Necessary for } \\
\text { Accomplishi } \\
\text { ng Tasks }\end{array}$ & $\begin{array}{l}\text { Pearson } \\
\text { Correlatio }\end{array}$ & .042 & .238 & .201 & .181 \\
\hline
\end{tabular}

TABLE III. CROSS TABULATION

\begin{tabular}{|c|c|c|c|c|c|c|}
\hline \multirow{2}{*}{\multicolumn{2}{|c|}{ Particulars }} & \multicolumn{4}{|c|}{ Experience } & \multirow[b]{2}{*}{ Total } \\
\hline & & \multirow{2}{*}{$\begin{array}{r}\begin{array}{l}0-5 \\
\text { yrs }\end{array} \\
2\end{array}$} & \multirow{2}{*}{$\begin{array}{c}5-10 \\
\text { yrs }\end{array}$} & \multirow{2}{*}{$\begin{array}{c}\begin{array}{c}10-15 \\
\text { yrs }\end{array} \\
2\end{array}$} & \multirow{2}{*}{$\begin{array}{l}\begin{array}{c}\text { More } \\
\text { than } \\
\text { 15 yrs }\end{array} \\
1\end{array}$} & \\
\hline JD & $\begin{array}{l}\text { Strongly } \\
\text { Disagree }\end{array}$ & & & & & 8 \\
\hline \multirow{4}{*}{$\begin{array}{l}\text { Versatility } \\
\text { in the Job }\end{array}$} & Disagree & 5 & 7 & 1 & 0 & 13 \\
\hline & Neutral & 38 & 24 & 16 & 5 & 83 \\
\hline & Agree & 48 & 34 & 16 & 10 & 108 \\
\hline & $\begin{array}{l}\text { Strongly } \\
\text { Agree }\end{array}$ & 22 & 25 & 23 & 18 & 88 \\
\hline \multicolumn{2}{|l|}{ Total } & 115 & 93 & 58 & 34 & 300 \\
\hline
\end{tabular}

TABLE IV. ChI-SQUARE TEST

TABLE V. Directional Measures

\begin{tabular}{|c|c|c|c|c|c|c|}
\hline \multicolumn{2}{|c|}{ Particulars } & & Value & Asymp. Std. Error & Approx. T & Approx. Sig. \\
\hline \multirow[t]{7}{*}{ Nominal by Nominal } & \multirow[t]{4}{*}{ Lambda } & Symmetric & 0.056 & 0.029 & 1.845 & 0.065 \\
\hline & & $\begin{array}{l}\text { JD } \\
\text { Versatility in } \\
\text { the Job }\end{array}$ & \multirow[t]{2}{*}{0.078} & \multirow[t]{2}{*}{0.041} & \multirow[t]{2}{*}{1.843} & \multirow[t]{2}{*}{0.065} \\
\hline & & Dependent & & & & \\
\hline & & $\begin{array}{l}\text { Experience } \\
\text { Dependent }\end{array}$ & 0.032 & 0.043 & 0.751 & 0.453 \\
\hline & \multirow[t]{3}{*}{ Goodman and Kruskal tau } & $\begin{array}{l}\text { JD } \\
\text { Versatility in } \\
\text { the Job }\end{array}$ & \multirow[t]{2}{*}{0.028} & \multirow[t]{2}{*}{0.012} & & \multirow[t]{2}{*}{0.001} \\
\hline & & Dependent & & & & \\
\hline & & $\begin{array}{l}\text { Experience } \\
\text { Dependent }\end{array}$ & 0.025 & 0.011 & & 0.029 \\
\hline
\end{tabular}


TABLE VI. SYMmetric MEASURES

\begin{tabular}{|l|l|l|l|}
\hline \multicolumn{2}{|c|}{ Particulars } & \multicolumn{1}{|c|}{ Value } & Approx. Sig. \\
\hline $\begin{array}{l}\text { Nominal } \begin{array}{l}\text { Nomial by } \\
\end{array} \\
\text { N }\end{array}$ & 0.283 & 0.02 \\
\cline { 2 - 4 } & Cramer's V & 0.163 & 0.02 \\
\hline Cases Valid & 300 & \\
\hline
\end{tabular}

TABLE VII. DESCRIPTIVES

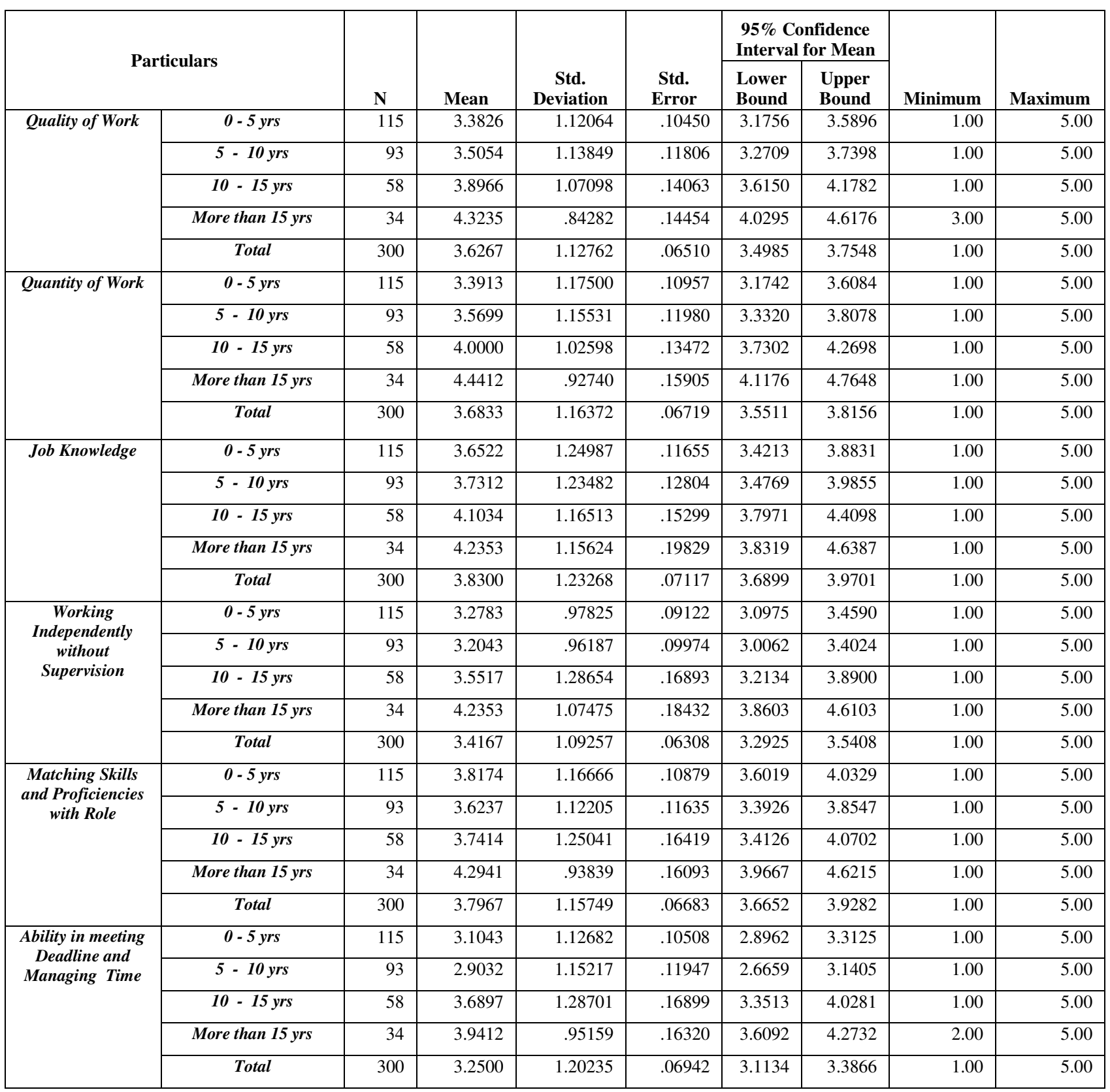




\begin{tabular}{|c|c|r|r|r|r|r|r|r|r|}
\hline $\begin{array}{c}\text { Identifying Top } \\
\text { Accomplishments }\end{array}$ & $\mathbf{0 - 5}$ yrs & 115 & 3.6348 & 1.25887 & .11739 & 3.4022 & 3.8673 & 1.00 & 5.00 \\
\cline { 2 - 10 } & $\mathbf{5}-\mathbf{1 0}$ yrs & 93 & 3.3118 & 1.15136 & .11939 & 3.0747 & 3.5489 & 1.00 & 5.00 \\
\cline { 2 - 10 } & $\mathbf{1 0}-\mathbf{1 5}$ yrs & 58 & 3.8103 & 1.35668 & .17814 & 3.4536 & 4.1671 & 1.00 & 5.00 \\
\cline { 2 - 10 } & More than 15 yrs & 34 & 4.4118 & .85697 & .14697 & 4.1128 & 4.7108 & 1.00 & 5.00 \\
\cline { 2 - 9 } & Total & 300 & 3.6567 & 1.24524 & .07189 & 3.5152 & 3.7981 & 1.00 & 5.00 \\
\hline
\end{tabular}

TABLE VIII. ANOVA

\begin{tabular}{|c|c|c|c|c|c|c|}
\hline \multicolumn{2}{|l|}{ Particulars } & $\begin{array}{c}\text { Sum of } \\
\text { Squares }\end{array}$ & df & Mean Square & $\mathbf{F}$ & Sig. \\
\hline \multirow[t]{3}{*}{ Quality of Work } & Between Groups & 28.954 & 3 & 9.651 & 8.134 & .000 \\
\hline & Within Groups & 351.233 & 296 & 1.187 & & \\
\hline & Total & 380.187 & 299 & & & \\
\hline \multirow[t]{3}{*}{ Quantity of Work } & Between Groups & 36.347 & 3 & 12.116 & 9.730 & .000 \\
\hline & Within Groups & 368.569 & 296 & 1.245 & & \\
\hline & Total & 404.917 & 299 & & & \\
\hline \multirow[t]{3}{*}{ Job Knowledge } & Between Groups & 14.467 & 3 & 4.822 & 3.245 & .022 \\
\hline & Within Groups & 439.863 & 296 & 1.486 & & \\
\hline & Total & 454.330 & 299 & & & \\
\hline \multirow{3}{*}{$\begin{array}{l}\text { Working Independently without } \\
\text { Supervision }\end{array}$} & Between Groups & 30.240 & 3 & 10.080 & 9.134 & .000 \\
\hline & Within Groups & 326.676 & 296 & 1.104 & & \\
\hline & Total & 356.917 & 299 & & & \\
\hline \multirow{3}{*}{$\begin{array}{c}\text { Matching Skills and Proficiencies with } \\
\text { Role }\end{array}$} & Between Groups & 11.424 & 3 & 3.808 & 2.896 & .035 \\
\hline & Within Groups & 389.173 & 296 & 1.315 & & \\
\hline & Total & 400.597 & 299 & & & \\
\hline \multirow{3}{*}{$\begin{array}{c}\text { Ability in meeting Deadline and } \\
\text { Managing Time }\end{array}$} & Between Groups & 41.077 & 3 & 13.692 & 10.361 & .000 \\
\hline & Within Groups & 391.173 & 296 & 1.322 & & \\
\hline & Total & 432.250 & 299 & & & \\
\hline \multirow[t]{3}{*}{ Identifying Top Accomplishments } & Between Groups & 31.870 & 3 & 10.623 & 7.283 & .000 \\
\hline & Within Groups & 431.767 & 296 & 1.459 & & \\
\hline & Total & 463.637 & 299 & & & \\
\hline
\end{tabular}

From Table 6, it infers that 115 respondents in the experience of $0-5 \mathrm{yrs}$ met expectations in the quality of work. The rest of the respondents in the experience of $0-$ 5 yrs agree often exceeded expectation in the quality of work. The result also infers that 115 respondents in the experience of $0-5$ yrs met expectations in the quantity of work. The rest of the respondents in the experience of $0-$ 5 yrs agree often exceeded expectation in the quantity of work. Irrespective of experience all the respondents were often exceeded expectation in the job knowledge. One hundred and fifteen respondents in the experience of $0-5$ yrs met expectations in working independently without supervision. Thirty four respondents in the experience of 0 - 5 yrs often exceeded expectation in working independently without supervision. Irrespective of experience all the respondents were often exceeded expectations in matching their skills and

proficiencies with the role. One hundred and fifteen respondents in the experience of $0-5 \mathrm{yrs}$ met expectations regards ability in meeting deadlines and managing time effectively. Fifty eight respondents in the experience of 10 -15 yrs often exceeded expectations regards ability in meeting deadlines and managing time effectively. Ninety three respondents in the experience of 5-10 yrs met expectations in identifying top accomplishments during the performance review. Rests of the respondents were often exceeded expectations in identifying top accomplishments during the performance review.

From Table 7, there is a significance variance between experience of the respondents and performance attributed. Since the significance value is less than 0.05 . Accept all alternative Hypotheses H2a, H2b, H2c, H2d, H2e, H2f and $\mathrm{H} 2 \mathrm{~g}$. Hence there is significance variance between experience of the respondents and their responses towards quality of work, quantity of work, working independently without supervision, matching of skills and proficiencies with the role, ability in meeting deadlines and managing time effectively, identifying top accomplishments during the performance review.

\section{FINDINGS AND CONCLUSIONS}

The researcher has used correlation analysis and found that 300 employees working in IT have a positive correlation $(0.218)$ between freedom in expressing views, 
concerns and the respondent's competitiveness towards the job. The study also found that there is a positive correlation $(0.233)$ between influencing the decision that affects the respondents and the respondent's being resourcefulness. The study also found that there is a positive correlation between (0.238) the support and authority to make the decisions necessary for accomplishing the tasks and the respondent's being initiative. Using chi-square analysis, the researcher revealed that there is a significant difference between the experience of the respondents and their response towards feeling versatility in their job which has greater scope for career growth. It is inferred that 88 respondents out of 300 (29\%) strongly agreed that they were able feel versatility in their job which has greater scope for career growth. The table also infers that 108 respondents out of $300(36 \%)$ agreed that they were able feel versatility in their job which has greater scope for career growth. Eighty three respondents out of $300(28 \%)$ were neutral in feeling versatility in their job which has greater scope for career growth. The table also infers that 13 respondents out of $300(4 \%)$ disagreed in feeling versatility in their job which has greater scope for career growth. Only 8 respondents out of $300(3 \%)$ strongly disagreed in feeling versatility in their job which has greater scope for career growth.

The researcher has used one way Anova to find the significant variance between experience of the respondents and the performance attributes. Hence the significance value is less than 0.05 , the alternate hypothesis is accepted that there is significant variance between experience of the respondents and their responses towards quality of work, quantity of work, working independently without supervision, matching of skills and proficiencies with the role, ability in meeting deadlines and managing time effectively, identifying top accomplishments during the performance review.

\section{RECOMMENDATIONS OF THE STUDY}

A healthy organizational culture values each employee in the organization regardless of his job duties, which results in employees working as a team to meet the company's and their own personal needs. Healthy organizational culture improves the performance of a business in a number of areas. It is found that there is a positive relationship between freedom in expressing views, concerns and the respondent's competitiveness towards the job. Hence it is suggested that the employees of the organization need to be encouraged to share their views and concerns related to their job for the growth of the organization. Since the respondents being resourcefulness has a direct impact on the respondent's influence of the decisions that affects them, it is suggested to the management to consider employee's concern before taking a decision which is related to their job or career. Since, the respondents to be initiate is dependent on the support and authority to make decisions necessary for accomplishing their tasks, it is suggested to the management to provide the complete support to the employees and defining their authority in making decisions for executing their tasks.
Also, since the experience of the employees has significant relationship with feeling versatility in their job, it is recommended the management to design the job description and role clarity of the employees in a way which has versatility in their role with a greater scope for career growth. It is further suggested to the management to pay high attention and provide importance to the experience which inducting or assigning critical tasks, since the experience of the employees has direct impact with quality of work, quantity of work, working independently without supervision, matching of skills and proficiencies with the role, ability in meeting deadlines and managing time effectively, identifying top accomplishments during the performance review.

\section{FUTURE DIRECTIONS OF THE STUDY}

This research considered the organizational culture dimensions impacting employee's performance in IT industry. The study can be expanded to the other industrial sectors with respect to the same topic. This research was limited to organizational culture dimensions of job rotation, employee rights and empowerment impacting employee's performance in IT industry. The researchers can cover the various other aspects of the organizational culture dimensions impacting performance of employees.

\section{REFERENCES}

[1] A Moeed Abid, Ambreen Sarwar, Kashif Imran, Abdul Jabbar, Abdul Hannan, "Effect of Job Design on Employee Satisfaction", European Journal of Business and Management, Vol.5, No.19, 2013, pp. $1-7$.

[2] Abdul Hameed and Aamer Waheed. "Employee Development and It's Affect on Employee Performance: A Conceptual Framework", International Journal of Business and Social Science, Vol. 2, No. 13, Jul 2011, pp. $224-229$.

[3] Anas Ghazi, Alam Edien, "Effects of Job Analysis on Personnel Innovation, International" Journal of Business and Management Invention, Vol. 4, No. 10, Oct 2015, pp. 09-18.

[4] Anbarasu Thangavelu, Dr. Clement Sudhahar, "Role Clarity and Job Performance among the Employees in Small and Medium IT Industries", Research on Humanities and Social Sciences, Vol.7, No.17, 2017, pp. 6- 10.

[5] Dia Zeglat, Mohammad Aljaber, Wasfi Alrawabdeh, "Understating the Impact of Employee Empowerment on Customer-Oriented Behavior", Journal of Business Studies Quarterly, Vol. 6, No. 1, 2014, pp. $55-67$.

[6] Hasan Hüseyin UZUNBACAK, "The Impact of Employee Empowerment on Innovation", The Journal of International Social Research, Vol. 8, No. 37, Apr 2015, pp. 977 - 989.

[7] Hasan Raza, Mehmood Anjum and Syed Muhammad Zia, "The impact of employee's job performance behavior and organizational culture on organizational productivity in pharmaceutical industries in Karachi”, Interdisciplinary journal of contemporary research in business, Vol 5, No.12, Apr 2014, pp. 385 - 400.

[8] Jalal Hanaysha, Putri Rozita Tahir, "Examining the effects of Employee Empowerment, Team work and Employee Training on Job Satisfaction", Proceida Social and Behavioral Sciences, Vol. 219, 2016, pp. $272-282$. 